원 저

폐암 환자에서 방사선치료가 세포성 면역반응에 미치는 영향

\author{
순천향대학교 의과대학 내과학교실 \\ 어 수 택·김 철 현·정 연 태 \\ 김 용 훈-박 춘 식・이 희 발 \\ 치료방사선과학교실 \\ 허 승 재
}

$=$ Abstract $=$

\title{
The Effect of Radiation Therapy on Cellular Immune Response in Patients with Squamous Cell Lung Carcinoma
}

Soo Taek Uh, M.D., Chul Hyun Kim, M.D., Yeon Tae Chung, M.D.

Yong Hun Kim, M.D., Choon Sik Park, M.D. and Hi Bahl Lee, M.D.

Department of Internal Medicine, College of Medicine, Soonchunyhyang University, Seoul, Korea.

\author{
Seung Jae Huh, M.D. \\ Department of Therapeutic Radiology
}

The immune staus is known to be decreased in malignant disease and radiation therapy (RT), used as a therapeutic tool, further decrease this-attenuated immune status. We measured the number of peripheral lymphocytes, its subsets and lymphoblast transformation for PPD, PHA, monoclonal antibodies including anti-CD3 and anti-CD2 before and after RT in 19 patients with squamous cell lung cancer to search the fine mechanism behind the RT-induced attenuation of lymphoblast transforamtion for mitogens and antigen.

The results were as follows;

1) The number of lymphocytes and its subsets decreased significantly after RT, but the percentages of lymhocyte subsets did not change aftr $\mathrm{RT}$ except interleukin-2 receptor positive $\mathrm{T}$ lymphocytes.

2) The function of lymphoctes, measured by lymphoblast tranformation for PHA and PPD, decrased after RT and the compositions of PBMC used for lymphoblast transformtion were not different before and after RT.

3) The mitosis of lymphocytes to anti-CD2 or anti-CD3 decreased significantly after RT. And IL-2 plus anti-CD3 increased the mitosis than that of anti-CD3 only after RT, but before RT there was no difference.

In conclusion, we suggested the fine mechanism behind the RT-induced attenuation of immune response might be the dysfunction of lymphocytes in terms of impaired synthesis of IL-2 rather than the decrease of circulating lymphocyte numbers. 


\section{서}

\section{론}

면역기전이 많은 종류의 암의 발생, 증식및 개체의 저 항성과 연관성이 있다는 것은 주지의 사실이달. 치료 받지 않은 악성종양, 즉 Hodgkin's 병이나 식도암 환자 에서 생체내 세포매개성 변역반응 검사인 지연성 피부 과민반응의 저하리칯 생체외 검사인 phytohemagglutinin(이하 PHA로 약함)자극에 대한 임파구의 단백 형성 장애 ${ }^{3)}$ 등은 악성종양 환자에서 세포매개성 면역반 응이 감소되어 있는 증거가 된다. 이의 원인으로 억제 단구에 의하여 형성되는 prostaglandin E2에 의한 억 제4) 및 임파구에서 interleukin-2(이하 IL-2로 약함) 형 성의 부적절한 생산등5)이 보고되고 있다.

악성 종양환자에서 치료의 한 방법으로 이용되는 방사 선 치료는 면역기능이 저하된 종양환자의 면역 기능을 더욱 악화시킬 수 있다. 종격동의 방사선 치료후 식도암 환자에서 생체외 검사인 PHA에 대한 임파아구 증식의 감소와 antibody dependent cell-mediated cytotoxity 의 저하가 관찰되며 Hodgkin's 병에서도 방사선 치료후 총 임파구 및 조력/억제 임파아구 비율의 감소를 보고하 고 있다 ${ }^{6,7)}$. 이러한 보고들은 방사선 요법후의 세포매개 성 면역기능 저하가 임파구의 숫적 감소와 임파구의 기 능적 변화에 의한 것임을 시사하는 소견이라 할 수 있으 나 세포매개성 면역반응 감소의 정확한 기전이 밝혀지지 않고 있다 ${ }^{8 \sim 11}$.

IL-2는 항원 특이성 임파구에서 항원에 의한 자극 및 단구세포의 도움으로 분비되어 임파구의 활성화 및 증식 에 필수적으로 요구되는 것으로 알려져 있으며, T-cell receptor에 대한 단세포군 항체인 anti-CD3 monoclonal antibody(이하 anti-CD3로 약함)는 항원처럼 단구 의 보조하에 antigen specific T-cell receptor complex인 nonpolymorphic subunit를 통해 임파구를 활 성화시키는데 ${ }^{12)}$ 반하여 T-cell receptor에 대한 다른 단 세포군 항체인 anti-CD2 monoclonal antibody(이하 anti-CD2로 약함) 는 단구의 보조 없이도 임파구를 활성 및 증식시킬 수가 있다고 알려져 있다 ${ }^{13)}$. 따라서 anti-CD2와 anti-CD3를 이용하여 단구 및 임파구의 기 능을 단독적으로 분석할 수 있으며 $\mathrm{IL}-2$ 를 첨가함으로 써 임파구 기능의 감소가 IL-2 형성능의 부족으로 인한 것인지를 분석할 수 있다.
저자들은 방사선 치료에 따른 면역기능 저하의 기전을 자세히 분석하고자, 편평세포 폐암환자에서 방사선 치 료 전후에 말초혈액 단핵구 세포를 anti-CD3, antiCD2 및 IL-2와 anit-CD3를 병용 투여한 후 임파아구 증식 (lymphoblast transformation)을 측정 비교하였다.

\section{대상 및 방법}

\section{1. 대 상}

기관지내시경 검사를 통하여 조직학적으로 확진된 편 평세포 폐암 환자 19명을 대상으로 하였다. 연령분포는 50 세에서 75 세로 평균연령은 65세였고 남자 16 명, 여자 3 명이었다. 모든 환자군에서 간이나 골수로의 암세포전 이가 없음이 방사선 동위원소 검사를 통해 확인되었고 병 기는 new international staging system ${ }^{14)}$ 에 의 거 모두 IIIa, IIIb 군에 속하였다. Performance stage는 $70 \%$ 이상의 Karnofsky scale ${ }^{15)}$ 이었다. 전 환자는 6 주 에서 8주간 종격동 부위에 5000-5500 rad의 방사선 조 사를 시행하였다. 정상대조군은 호흡기 증상이나 다른 감염의 증거가 없는 건강한 41 명을 대상으로 하였다.

\section{2. 말초정맥혈의 단핵구 세포 분리}

방사선 치료전과 종결 1-2일후에 Ficoll-Hypaque 경 사 윈침법(gradient centrifugation) ${ }^{16}$ )에 의해 말초혈 액 단핵 구(peripheral blood mononuclear cell; $\mathrm{PBMC}$ ) 를 분리하였다. 간단히 요약하면 먼저 heparin 으로 처리된 정맥혈을 동량의 phosphate buffered saline(이하 PBS로 약함)으로 섞은 후 비중 1.078인 Ficoll-Hypaque에 중첩시켜 실온에서 45 분간 $500 \mathrm{~g}$ 로 원침시켜, Ficoll-Hypaque의 상층부에 형성된 $\mathrm{PBMC}$ 층을 분리하여 PBS로 2희 세척하고 RPMI 1640 (Gibco, USA) (Tissue culture medium; 이 하 TCM 으로 약함)에 $1 \times 10^{6} \mathrm{cells} / \mathrm{ml}$ 가 되게 재부유하였다.

\section{3. 임파구 아형의 측정}

측정 방법은 단세포군항체 (monoclonal antibody, Becton-Dickinson Co.) 인 Leu4 (CD3), Leu3 (CD4), Leu2 (CD8), Leu 11b (NK cell), anti-human IgM (B-cell), CD25 (anti-IL2 receptor positive cell)를 사 용하였다. 간략히 기술하면, $2 \%$ bovine serum albu$\min (\mathrm{BSA})$ 과 $\mathrm{PBS}$ 가 함유된 $1 \times 10^{6} / \mathrm{ml} \mathrm{PBMC}$ 에 $5 \mu \mathrm{g}$ 
의 단세포군 항체를 가하여 $4^{\circ} \mathrm{C}$ 에서 30 분간 배양후 다시 $\mathrm{PBS}$ 로 2회 세척하였고 그후 FITC가 결합된 antimouse immunoglobulin (Becton-Dickinson, USA) 를 가하여 $4^{\circ} \mathrm{C}$ 에서 30 분간 배양하였다. 세척후 $\mathrm{PBMC}$ 를 재부유한 뒤 flow-cytometer (FACScan, BectonDickinson, USA) 를 이용하여 분석하였다. 말초혈액 단핵세포 감별산출은 Diff-Quick 염색법을 이용하였으 며 각 임파구 아형의 총수치를 coulter counter로 산출 된 임파구 총수에 각 임파구 아형의 백분율을 곱한 값으 로 정하였다.

\section{4. 체외증식 반응검사}

항원과 mitogen에 의한 임파아구 증식의 측정은 Levy 법 ${ }^{3)}$ 을 변형하여 이용하였다. 약술하면 $10 \%$ fetal calf serum이 함유된 $\mathrm{TCM}$ 에 $1 \times 10^{6} / \mathrm{ml}$ 로 부유된 $\mathrm{PBMC} 0.1 \mathrm{ml}$ 를 96 microplate의 각 well에 주입한 뒤 유사분열 물질인 $10 \mu \mathrm{g} / \mathrm{ml}$ 의 PHA, $10 \mu \mathrm{g} / \mathrm{ml}$ 의 purified protein derivatives(이하 PPD로 약함), 각각 $0.2 \mu \mathrm{g} / \mathrm{ml}$ 의 2종의 anti-CD2(9-1과 9.6) 또는 antiCD3(Memorial Sloan Kettering Cancer Center의 양 수영 박사로 부터 기증받았음) 그리고 $10 \mu \mathrm{g} / \mathrm{ml}$ 의 IL -2 (Genzyme, USA)를 병합한 anti-CD3를 각각 분주하 여 $5 \% \mathrm{CO}_{2}, 37^{\circ} \mathrm{C}$ 에서 $\mathrm{PHA}$ 에 의한 임파아구 증식은 72 시간, 그외의 경우는 96 시간동안 배양하였다. 배양종 료 16 시 간 전 $0.5 \mu \mathrm{Ci}[\mathrm{H}]^{3}$-thymidine $(6.7 \mathrm{ci} / \mathrm{mmol}$, New England Nuclear, Dupont, USA)를 각 well 에 분주하고 16시간후에 세포수집기 (Skatron, Norway) 를 이용하여 glass fiber filter(Skatron, Norway, Cat No 7031)에 모은후 건조시키고 $4 \mathrm{ml}$ 의 scintillation 용
액을 분주한 후 각각을 liquid scintillation counter (Packard 1500, Tri-carb USA) 로 측정하였다. 모든 검사는 동시에 사중(quadruple)으로 시행하여 평균치 를 구하였다.

\section{5. 통계 방법}

방사선 치료전후의 임파구 아형의 절대치와 평균치 및 임파아구 증식은 Wilcoxon's rank sum test를 이용하 였고, 환자군과 정상대조군의 각 수치의 비교는 MannWhitney U test를 이용하였다. 모든 자료는 $\mathrm{p}$ 값이 0.05 이하 일때 통계적으로 유의한 차이가 있는 것으로 판정 하였고 모든 자료는 평균士표준오차로 표시하였다.

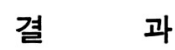

\section{1. 방사선 치료 전후의 임파구 및 아형의 변화}

말초혈액내 총 임파구의 숫자는 방사선 치료전의 폐암 환자에서 대조군에 비하여 유의하게 감소되어 있었으며 $\left(2731 \pm 199\right.$ vs $\left.1498 \pm 587 / \mathrm{mm}^{3}, \mathrm{p}<0.05\right)$, 방사선 치 료후 더욱 감소되었고 $\left(1498 \pm 287\right.$ vs $411 \pm 58 / \mathrm{mm}^{3}$, $\mathrm{p}<0.05)$, 모든 임파구아형의 숫자 또한 방사선 치료후 의미있게 감소되었다(Table 1). 임파구아형의 빈도수 에 있어서는 정상대조군과 방사선 치료전, 후 환자군 세 군에서 차이가 없었으나 IL-2 수용체 양성 임파구의 빈 도는 치료전의 폐암환자에서 상승되며 방사선 치료후에 더욱 상승되는 것을 관찰할 수 있었다(Table 2).

\section{PHA와 PPD에 의한 임파아구 증식}

방사선 치료전의 임파구 증식에 사용된 $\mathrm{PBMC}$ 내의

Table 1. The Effects of RT on Absolute Number of Lympinocy te Subsets

\begin{tabular}{|c|c|c|c|c|}
\hline \multirow{2}{*}{ Parameter $\left(/ \mathrm{mm}^{3}\right)$} & \multirow{2}{*}{ Normal donors } & \multicolumn{3}{|c|}{ Patients with lung carcinoma } \\
\hline & & Before RT & After RT & $\mathrm{P}$ \\
\hline Lymphocyte & $2731 \pm 119^{*}$ & $1498 \pm 287$ & $411 \pm 58$ & 0.005 \\
\hline Leu 4 & $1699 \pm 82 *$ & $885 \pm 208$ & $224 \pm 55$ & 0.005 \\
\hline Leu3 & $980 \pm 51^{*}$ & $591 \pm 115$ & $166 \pm 36$ & 0.003 \\
\hline Leu 2 & $476 \pm 101$ & $428 \pm 89$ & $129 \pm 35$ & 0.012 \\
\hline Leu $11 \mathrm{~b}$ & $109 \pm 30$ & $103 \pm 32$ & $26 \pm 6$ & 0.016 \\
\hline anti-numan $\operatorname{lg~} \mathrm{Ml}$ & $114 \pm 42$ & $107 \pm 39$ & $17 \pm 6$ & 0.011 \\
\hline CD 25 & $11 \pm 2^{*}$ & $48 \pm 17$ & $8 \pm 3$ & 0.018 \\
\hline
\end{tabular}

* $\mathrm{P}<0.05$ vs before RT 
Table 2. The Efrects of RT on the Percentage of Lymphocyte Subsets

\begin{tabular}{lcccc}
\hline \hline \multirow{2}{*}{ Parameter } & Normal donors & & Patients with lung carcinoma \\
\cline { 2 - 5 } & & Before RT & After RT & P \\
\hline Leu4 & $63.7 \pm 2.0$ & $60 \pm 3$ & $60 \pm 4$ & NS \\
\% Leu3 & $36.8 \pm 1.14$ & $38 \pm 2$ & $36 \pm 2$ & NS \\
\% Leu2 & $27.1 \pm 0.9$ & $25 \pm 2$ & $26 \pm 2$ & NS \\
\% OK Leu3/Leu2 & $1.4 \pm 0.1$ & $1.4 \pm 0.1$ & $7.5 \pm 0.5$ & NS \\
\% Leu 11b & $7.4 \pm 1.3$ & $7.3 \pm 1.6$ & $5.2 \pm 1.8$ & NS \\
\% anti-human Ig M & $7.8 \pm 1.0$ & $6.9 \pm 2.0$ & $5.6 \pm 1.3$ & 0.03 \\
\hline CD 25 & $0.4 \pm 0.1 \#$ & $2.6 \pm 0.7$ & & \\
\hline
\end{tabular}

* There were no differences in any of lymphocyte subsets between normal control and before RT groups except $\% \mathrm{CD} 25$.

\# $\mathbf{P}<0.05$ vs before RT.

Table 3. The Effects of RT on Lymphoblast Transformation for PHA and PPD

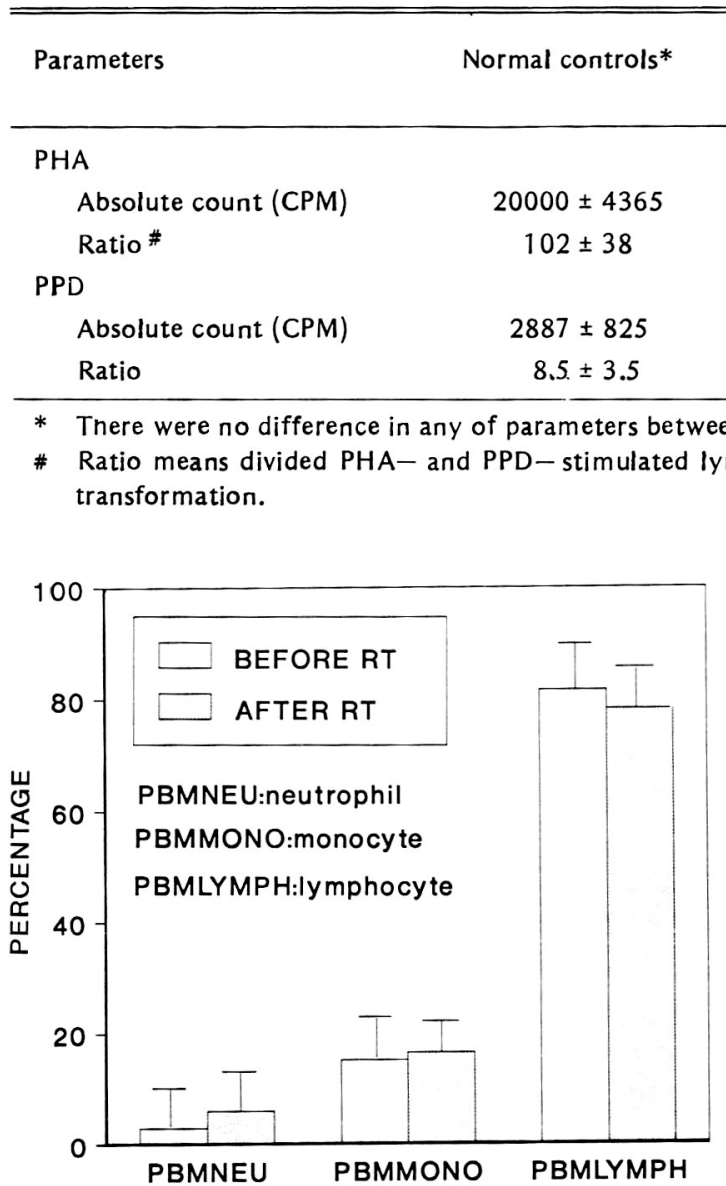

Fig. 1. The compositions of PBMC used in lymphoblast transforamtion were not different before and after RT.
조성은 치료후와 비교하여 임파구( $85 \pm 2$ vs $84 \pm 4 \%$ ), 단구( $18 \pm 4$ vs $20 \pm 4 \%)$, 호중구( $5 \pm 2$ vs $8 \pm 3 \%$ ) 모두 에서 차이가 없었다(Fig 1). PHA에 의한 임파아구 증 식은 방사선 치료전에 비해 치료후가 유의하게 감소하였 고(23603 \pm 4717 vs $9434 \pm 4380 \mathrm{CPM}, \mathrm{p}<0.05)$, 또한 $\mathrm{PPD}$ 에 의한 임파아구 증식에서도 유의하게 감소하였다 $(2459 \pm 794$ vs $608 \pm 232 \mathrm{CPM}, \mathrm{p}<0.05)$. 또 한 mitogen에 의한 임파아구 증식을 자연적인 (spontaneous) 임파아구 증식으로 나눈 자극지수(stimulation index) 도 방사선 치료전에 비해 치료후가 $\mathrm{PHA}(107 \pm$ 44 vs $23 \pm 8, \mathrm{p}<0.05), \operatorname{PPD}(7.9 \pm 3.1$ vs $1.7 \pm 0.6$, $\mathrm{p}<0.05)$ 모두에서 유의하게 감소되었다. 그러나 정상 대조군과 방사선 치료전 환자군 사이에서는 임파아구 증 식의 절대치와 자극지수는 차이를 보이지는 않았다 (Table 3). 


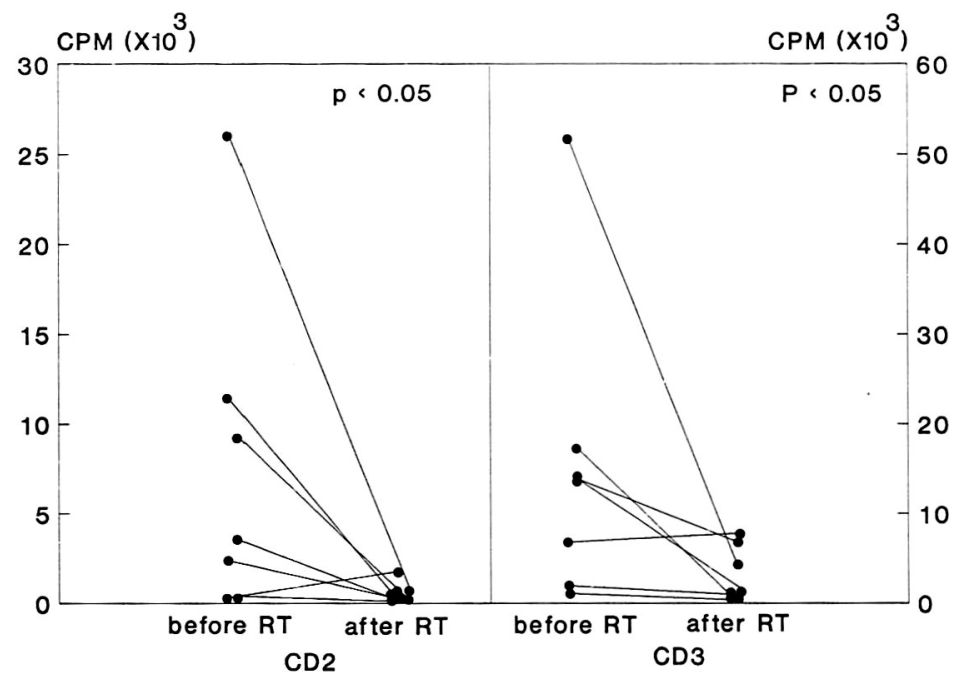

Fig. 2. In vitro blast transformation to $\mathrm{CD} 2$ and $\mathrm{CD} 3$ was depressed after $\mathrm{Rt}$ when compared with that of before RT.

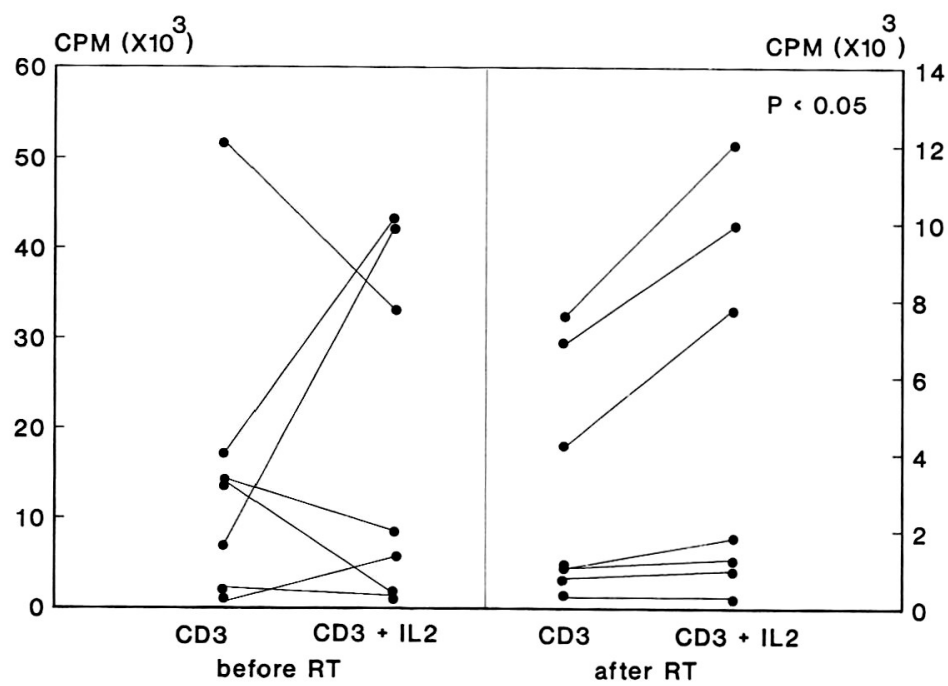

Fig. 3. In vitro blast transformation to $\mathrm{CD} 3$ plus $\mathrm{IL}-2$ was increased after RT, but there was no increase in before RT.

\section{Anti-CD2, CD3와 IL-2에 대한 임파아구 증식}

Anti-CD2(9-6과 9.1)에 의한 임파아구 증식은 검사 된 7명의 환자중 6 명의 환자에서 방사선 치료전에 비해 치료후 현저히 감소되었으며 $(\mathrm{p}<0.05)$, 그리고 anti$\mathrm{CD} 3$ 에 대한 반응도 anti-CD2와 같은 소견을 보였다
( $\mathrm{p}<0.05$, Fig. 2). 방사선 치료전에는 anti-CD3 단독 에 의한 임파아구 증식과 anti-CD3 및 IL-2의 병용 투여 시의 임파아구 증식에는 차이가 없었으나, 방사선 치료 후에는 검사된 7예 모두에서 anti-CD3와 IL2 병용 투여 시의 임파아구 증식이 anti-CD3 단독에 의한 임파아구 증식보다 증가되어 있었다 $(\mathrm{p}<0.05$, Fig. 3$)$. 
본 연구에서 저자들은 단세포군 항체을 사용하여 편평 세포 폐암환자에서 방사선 치료가 세포성 면역기능에 미 치는 영향에 대해서 알아보았다. 방사선 치료후 임파아 구 및 그 아형의 수가 유의하게 감소하였고 또한 임파아 구의 기능으로 표시되는 임파아구 증식도 유의한 감소를 보였지만, IL-2 수용체 양성인 임파구를 제외하고는 임 파아구의 비는 감소하지 않았다. 상기소견은 방사선 치 료후 말초혈액내 세포성 면역반응에 역활을 하는 임파구 의 조성의 변화보다는 숫적 감소가 방사선 치료후 세포 성 면역반응의 억제에 큰 역활을 할 수 있으리라고 시사 된다.

Hodgkin's병등 악성종양에서 방사선 치료후 유발되 는 면역변화 ${ }^{1721)}$ 는 본 연구에서도 관찰된 바와 같이 임 파구 감소와 연관된 것으로 알려져왔다. Schulof ${ }^{22)}$ 등은 이러한 임파구의 숫적 감소는 방사선 치료 영역내의 혈 량(volume of blood) 및 골수량 (volume of bone marrow) 과 관계있다고 추정하였고, Benningoff ${ }^{23)}$ 는 홍선 내에 $\mathrm{T}$ 임파구가 분리(sequestration)되어 말초순환에 서 임파구가 저하된다고 하였으나 그 정확한 기전은 현 재 밝혀져있지 않다. 반면에 방사선 치료후 $\mathrm{T} 4 / \mathrm{T} 8$ 비율 의 변화에 대해서는 보고자마다 다양한 변화를 보고하고 있다 ${ }^{8,10,22)}$. Posner ${ }^{8)}$ 는 Hodgkin's병 환자에서 방사선 치료후 $\mathrm{T} 4 / \mathrm{T} 8$ 비의 감소가 관찰되고 이가 면역상태의 변화에 큰 영향을 미치므로 $\mathrm{T} 4$ 의 역할에 대해서 강조하 였다. 그는 방사선 치료후의 T4/T8의 비의 감소는 다 음과 같은 이유라고 설명하고 있다. 첫째, 체내에서 $\mathrm{T} 4, \mathrm{~T} 8$ 의 분포에 차이가 있기 때문에 ${ }^{24,25)}$ 방사선 치료 시 치료 영역에 의해 $\mathrm{T} 4$ 가 선택적으로 감소되며, 둘째 여러가지 방법으로 증명된 ${ }^{26 ~ 28)}$ suppressor cell의 활성 화를 그 이유로 제시하였다. 그러나 본 연구에서는 방사 선 치료후 $\mathrm{T} 4 / \mathrm{T} 8$ 비율의 변화는 관찰되지 않았고 이는 Schulof등 22)이 폐암환자에서 시행한 종격동 방사선 치 료가 $\mathrm{T} 4 / \mathrm{T} 8$ 비율에 변화를 주지 않았다는 보고와 일치 하는 결론이었다. Posner 와의 차이점은 아마도 방사선 치료용량의 차이, 즉 저자들은 5000 5500 rad 였으며 Posner등은 3600 4000 rad인 점이 방사선 치료후의 $\mathrm{T} 8$ 의 차이를 야기시켰을 것으로 사료되며, 방사선 치료 후의 T8의 현저한 감소는 suppressor T-cell이 방사선
조사에 예민하기 때문일 것으로 사료된다 ${ }^{29,30)}$.

예기치 않게 방사선 치료후 IL-2 수용체 양성 임파구 백분율이 치료전 보다 유의하게 증가하였으며, 이런 현 상은 $\mathrm{T}$ 임파구가 현저히 감소한데 비하여 IL-2 수용체 양성 임파구의 감소는 미미하였기 때문으로 추측되나, 방사선 치료에 따른 조직의 변화가 새로운 항원성으로 작용되어 IL-2 수용체 양성 임파구 증가의 원인이 되었 을지는 배제할 수 없다. 또한 Rovelli등1)이 폐암환자에 서 IL-2 receptor의 분비 및 수용성 형태 ${ }^{32)}$ 인 수용성 IL -2 receptor의 증가를 보고하여 본 실험에서의 결과와 관계있을 것으로 추측된다. 방사선 치료후 $\mathrm{PHA}$ 와 $\mathrm{PPD}$ 에 대한 임파아구 형성의 감소는 방사선치료가 직 접적으로 임파구와 단구세포에 영향을 미친다고 사료되 었다. 물론 임파아구형성 실험에 사용된 단핵구세포의 세포조성의 변화가 예측 되었으나 저자의 경우 방사선 치료후 PBMC의 조성 및 임파구아형의 변화가 없음을 관찰하였다. IL-2 형성에는 물론 단구세포의 도움이 필 요함으로 단구세포의 기능이상에서도 상기 현상은 설명 될 수 있으며 추후 단구세포의 기능 및 임파구에서 IL-2 형성능을 직접 측정함으로써 방사선 치료에 따른 임파아 구 형성의 장애가 임파구나 단구세포의 직접적인 기능적 이상으로 초래됨을 관찰할 수 있을 것이다. 그리고 정상 대조군과 방사선치료 전의 군과의 임파아구 증식이 차이 가 없었던 점은 Posner $^{8)}$ 의 보고와 일치하는 소견이지만 환자군의 수를 증가시킬 경우 그 차이는 있을 것으로 추 측되나 추후 연구과제가 될 것으로 사료된다.

말초 임파구와 단핵구의 기능을 평가하기 위하여 본 저자들은 순수하게 분리된 임파구나 단구세포를 혼합 배 양하는 실험 대신에 임파구와 단구를 함유한 $\mathrm{PBMC}$ 를 이용하였다. 그리고 본 연구에서는 PHA에 의한 임파아 구증식의 배양시간은 72 시간 이었으며, 다른 유사분열 물과 항원에 의한 배양시간은 96시간 이었던바, 이는 기 술하지는 않았지만, 저자들의 예비 실험에 의해 임파아 구 증식이 가장 높았던 시간들이었다.

Anti-CD2 antibody(9.6과 9-1)는 T-cell의 증식에 있어 단핵구 같은 항원인지세포 (antigen presenting cell) 없이도 가능한데 ${ }^{33)}$ 비하여 anti-CD3는 항원 인지 세포를 필요로 하며 ${ }^{12,34 ~ 37)}$, 그 경로는 CD2 pathway ${ }^{38)}$ 를 통한 $\mathrm{CD} 3 / \mathrm{Ti}$ Complex 형성 ${ }^{39 \sim 41)}$ 으로 $\mathrm{T}$ 세포 증식 을 유발시킬 수 있다. 이러한 T cell receptor에 대한 여러 항체의 다른 성질을 이용하여, 임파구와 단구의 기 
능을 분석하기 위해 임파구와 단구가 함유되어 있는 $\mathrm{PBMC}$ 에 anti-CD3로 임파아구 중식을 유발시킨 바, 방 사선 치료후 임파아구 증식이 감소됨을 관찰하였다. 이 는 방사선 치료후 단구 및 임파구의 기능적 결함을 추정 하는 소견이지만, 면역반응의 약화가 단구 및 임파구중 어느 세포에 기인한 것인지는 여전히 알 수는 없었다. 반면 anti-CD2(9.6과 9-1)에 의한 임파아구 증식은 임 파구의 기능만을 평가할 수 있어 치료후에 anti-CD2에 의한 자극 효과의 감소가 관찰되는 것으로 보아서는 임 파구의 장애가 생기는 것은 분명한 사실로 인식되었다.

이런 임파구의 기능적 감소가 IL-2 형성및 IL-2 수용 체의 발현에 문제가 될 수 있으나 IL-2 수용체는 오히려 상승되는 것으로 보아 IL-2 형성에 장애가 있다고 추정 되었고, IL-2 형성을 직접 측정하는 것이 가장 좋은 방 법이나 IL-2를 첨가함으로써 간접적으로 분석하여 보았 다. 방사선 치료 전후 IL-2와 anti-CD3를 동시에 투여 하여 임파아구 증식을 측정한 바, 방사선 치료전에는 IL -2 가 영향을 미치지 못하였으나, 방사선 치료 후 IL-2가 임파아구 증식을 증가시킴을 관찰할 수 있었다. 이러한 사실은 방사선 치료 전에는 IL-2 형성에 장애가 없었으 나 치료 후 임파아구의 기능적 결함 특히 IL-2 형성의 결함이 생기는 것으로 추정된다. 왜냐하면 IL-2가 대개 의 경우 활성화된 임파구에서 생성43)되어지지 때문이고 또한 악성종양의 면역치료시 IL-2가 사용되고 있고 그 효과가 보고되는 사실도 ${ }^{44)}$ 저자들의 실험과 무관치 않으 리라 생각된다.

\section{결 론}

악성질환에서 면역반응은 감소되어 있으며, 방사선 치료후 면역반응은 더욱 감소하지만 그 정확한 원인은 밝혀져 있지 않다. 이에 저자들은 방사선 치료후의 세포 매개성 면역반응 감소의 기전을 알아보고자 19 명의 편평 세포 폐암환자에서 단클론성 항체를 이용하여 방사선치 료 전후의 임파구 및 그 아형의 수 그리고 임파아구 증식 을 측정하여 다음과 같은 결론을 얻었다.

1) 방사선치료후 임파구 및 그 아형의 수는 치료전에 비해 현저히 감소 하였으나, IL-2 양성 T 임파구를 제 외한 임파구 아형의 비율은 방사선치료 전후 차이가 없 었다.

2) $\mathrm{PHA}$ 및 $\mathrm{PPD}$ 에 의한 임파아구 증식은 방사선 치
료전에 비해 치료후 현저히 감소하였으며, 임파아구 중 식에 사용된 말초단핵구의 구성비 및 임파구아형의 빈도 는 방사선 치료전후 차이가 없었다.

3) anti-CD2 및 anti-CD3에 의한 임파아구 중식은 방사선 치료전에 비해 치료후 현저히 감소하였다. 그리 고 방사선 치료후에는 IL-2와 anti-CD3 동시 투여에 의 한 임파아구 중식이 anti-CD3 단독 투여에 의한 임파아 구 증식보다 유의하게 중가되어 있었으나, 방사선 치료 전에는 양자간에 차이가 없었다.

이상의 결과로 방사선 치료후의 임파아구 중식의 감소 는 임파구의 구성의 변화에 의한 것보다는 임파구의 기 능적 변화 특히 IL-2 합성장애에 의한 것이라고 사료된 다.

끝으로 임파아구 측정의 면역형 광 검사에 도움을 주신 현암신장연구소의 전 복희, 김 은영 기사께, 그리고 체 외중식 반응검사에 도움을 주신 김 미호 기사께 진심으 로 감사를 드린다.

\section{REFERENCES}

1) Vathiere FD, Francois $P$, Hill $C$, Schweisguth $O$, Rodary C, Sarrazin D, Oberlin O, Beurtherst C, Dutreix A, Flamant A: Role of radiotherapy and chemotherapy in the risk of second malignant neoplasms after cancer in childhood. Br J Cancer 59: 792, 1989

2) Young RC, Corder MP, Haynes HA, DeVita VT: Delayed hypersensitivity in Hodgkin's disease. A study of 103 untreated patients. Am J Med 52:63, 1972

3) Levy R, Kaplan HS: Impaired lymphocyte function in untreated Hodgkin's disease. N Eng J Med 290: 181, 1974

4) Balch CM, Dpugherty PA, Tilden AB: Excessive prostaglandin $E_{2}$ production by supperssor monocytes in head and neck cancer patients. Ann Surg Dec 196:645, 1982

5) Marchiol C, Kaplan C, Chuaib S, Janvier M, Ferme C, Muller JY, Fradelizi D: Abnormal regulation in the production of IL2 in Hodgkin's disease. C R Acad Sc; [III] 301:283, 1985

6) Stanely E, Order MD: The effects of the therapeutic irradiation on lymphocytes and immunity. Cancer 39:737, 1977

7) Yokoyama Y, Sakamoto K, Arai M, Akagi M: 
Radiation and surgical stress induce a significant impairment in cellular immunity in patients with esophageal cancer. Jpn J Surg 19:535, 1989

8) Posner MR, Reinherz R, Lane H, Mauch P, Hellman S, Schlossman SF: Circulating lymphocyte populations in Hodgkin's disease after mantle and praaortic irradiation. Blood 61:705, 1981

9) Gray WC, Hasslinger BJ, Suter CM, Blanchard CL, Goldstein AL, Chretien PB: Suppression of cellular immunity by head and neck irradiation. Precipitating factors and reparative mechanisms in experimental model. Arch Otolaryngol Head Neck Surg 112:1185, 1986

10) Gray WC, Chretien PB, Suter CM, Revie DR, Tomazic VT, Blanchard CL, Aygun C, Amornmarn R, Ordonez JV: Effects of radiation therapy on $\mathrm{T}$. lymphocyte subpopulations in patients with head and neck cancer. Arch Otolaryngol Head Neck Surg 93:650, 1985

11) Monti G, Guerrini L, Magni E, Cruciani G, Bardella $D$. The mid-term effects of radiotherapy on $T$ and $B$ lymphocytes: An evaluation of cellular immunity with standard methods and monoclonal antibodies. Tumori 70:335, 1984

12) Kaneoka H, Perez-Rojas G, Sasuki T, Benike CJ, Engleman EG: Human $T$ lymphocyte proliferation induced by a pan- $T$ monoclonal anitbody (antiLeu4): Heterogenecity of response is a function of monocytes. J Immunol 131:158, 1983

13) Meuer SC, Hauer M, Kurz P, Buschenfelde KMZ, Köhler H: Selective blockade of the antigenreceptor mediated pathway of $T$ cell activation in patients with impaired primary immune function. J Clin Invest 80:743, 1987

14) Moutin CF: A new international staging system. Chest 89:225s, 1986

15) Karnofsky DA. Burchenal JH: The clinical evaluation of chemotherapeutic agents in cancer. In: Macleod CM, ed. Evaluation of Chemotherapeutic Agents. Sympoium, Microbiology Section, New York Academy of Medicine, 1948. New York: Columbia University Press, 191, 1949

16) Böyum A: Separation of leukocytes from blood and bone marrow. Scand J Clin Lab Invest 97:77, 1968

17) Hoppe RT, Fuks $Z Y$, Strober S, Kaplan HS: The long-term effects of radiation on $T$-and $B$ lymphocytes in the peripheral blood after regional irradiation. Caner 40:2071, 1977
18) Thomas JW, Coy P, Lewis HS, Yuen A: Effect of therapeutic irradiation on lymphocyte transformation in lung cancer. Cancer 17:1046, 1971

19) Kenady DE, Chretien PB, Potvin C, Simon RM, Alexander JC Jr, Goldstein AL: Effect of thymosin in vitro on $\mathrm{T}$-cell levels during radiation therapy. Cancer 39:642, 1977

20) Stratton JA, Byfield PE, Byfield JE, Small RC, Benfield J, Pilch Y: A comparison of the acute effects of radiation therapy, including or excluding the thymus, on the lymphocyte subpopulations of cancer patients. J Clin Invest 56:88, 1975

21) Trask CWL, Llewellyn I, Souhami RL: The effect of radiotherapy on blood mononuclear cell numbers and phagocyte migration. Clin Radiol 31:733, 1980

22) Schulof RS, Chorba TL, Cleary PA, Palaszynski SR, Albaster O, Goldstein AL: T-cell abnormalities after medastinal irradiation for lung cancer. The in vitro influence of synthetic thymosin alpha-1. Cancer 55:974, 1985

23) Benninghoff DL, Girodet RE, Porteus DD: Thoracic duct and blood lymphocytes in cancer. Lancet I:264, 1973

24) Poppema S, Bhan AK, Reinherz EL, McCluskey RT, Schlossman SF: Distribution of $T$ cell subsets in human lymph nodes. J Exp Med 153:30, 1981

25) Janossy G, Tidman N, Selby WS, Thomas JA, Granger S, Kung PC, Goldstein G: Human T lymphocytes of inducer and suppressor type occupy different microenvironments. Nature 288:81, 1980

26) Kotzin BL, Strober S: Reversal of NZB/NZW disease with total lymphoid irradiation. J Exp Med 150:371, 1979

27) Ritz J, Sallen SE, Bast RC, Lipton JM, Nathan DG, Schlossman SF: Autologous bone marrow transplantation in CALLA positive ALL following in vitro treatment with $\mathrm{J} 5$ monoclonal antibody and complement. Blood 58:175a, 1981

28) Forman SJ, Noecker P, Gallagher MT, Nolen J, Zaia J, Blume KG: Immune reconstitution following bone marrow trasplantation: patterns of $\mathrm{T}$-cell recovery. Blood 58:173a, 1981

29) Gupta S, Good RA. Subpopulations of human T lymphocytes: II. Effect of thymopoietin, corticosteroids and irradiation. Cell Immunol 34:10, 1977

30) Moretta L, Webb SR, Grossi CE, Lydyard PM, Cooper MD: Fuctional analysis of two human T-cell subpopulations: Help and suppression of B-cell re- 
sponses by $\mathrm{T}$-cells bearing receptors for IgM ( $\mathrm{Tu}$ ) or IgG (Tr). J Exp Med 146:184, 1977

31) Rovelli F, Lissoni P, Crispino S: Increased level of soluble interleukin-2 receptor in advanced solid tumors: a preliminary study. Tumori $\mathbf{7 4 : 6 3 3 , 1 9 8 8}$

32) Rubin LA, Nelson DL: The soluble interleukin-2 receptor: Biology, function, and clinical application. Ann Inter Med 113:619, 1990

33) Yang SY, Chouaib SH, Dupont B: A common pathway for $\mathrm{T}$ lymphocyte acitvation involving both the CD-3Ti complx and CD2 sheep eythrocyte receptor determinants. J Immunol 15:1097, 1986

34) Van Wauwe JP, deMey JR, Goossens JG: OKT3: a monoclonal antihuman $\mathrm{T}$ lymphocyte antibody with potent mitogenic properties. J Immunol 124: 2708, 1980

35) Meuer SC, Hodgdon JC, Hussey RE, Protentis JP, Schlossman SF, Reinherz EL: Antigen-like effects of monoclonal antibodies directed at receptors on human T cell clones. J Exp Med 158:988, 1983

36) Landegren U, Anderson J, Wigzell H: Mechanism of $\mathrm{T}$ lymphocyte activation of OKT3 antibodies: a general model for $\mathrm{T}$ cell induction. Eur $\mathrm{J}$ Immunol 14:325, 1984
37) Reinherz EL, Meuer SC, Schlossman SF: The human $\mathrm{T}$ cell receptor; analysis with cytotoxic $\mathrm{T}$ cell clones. Immunol Rev 74:83, 1983

38) Schulof RS, Lacher MJ, Gupta S: Abnormal phytohemagglutinin-induced T-cell proliferative responses in Hodgkin's disease. Blood 57:607, 1981

39) Meuer CS, Fitzgerald KA, Hussey RE, Hodgdon JC, Scholssmon SF, Reinerz EL: Clonotypic structures involved in antigen specific $T$ cell function: relationship to the T3 molecular complex. J Exp Med 157: 705, 1983

40) Borst J, Prendiville MA, Terhorst C: Complexity of the human $\mathrm{T}$ lymphocyte-specific cell surface antigen T3. J Immunol 128:1560, 1982

41) Oetgen H, Kappler J, Tax WJM, Terhost C: Characterizatin of the two heavy chains of the $\mathrm{T} 3 \mathrm{com}$ plex on the surface of human T lymphocytes. J Biol Chem 259:12039, 1983

42) Sith KA: Interleukin-2: inception, impact and implications. Science 240:1169, 1988

43) Rosenberg SA, Lotze MT: Cancer immunotherapy using interleukin-2 and interlukin-2-activated lymphocytes. Annu Rev Immunol 4:681, 1986 